Article

\title{
Effects of Urbanization on Rural Drinking Water Quality in Beijing, China
}

\author{
Lan Zhang ${ }^{1}$, Shenghua Gao ${ }^{1}$, Binggan Wei ${ }^{2}$, Yonghua $\mathrm{Li}^{2}$, Hairong $\mathrm{Li}^{2}$, Li Wang ${ }^{1}$ \\ and Bixiong Ye ${ }^{1,2, *}$ \\ 1 National Institute of Environmental Health, China CDC, Beijing 100021, China; zhanglan@chinacdc.cn (L.Z.); \\ gaosh@chinacdc.cn (S.G.); wangli@chinacdc.cn (L.W.) \\ 2 Institute of Geographical Sciences and Natural Resources Research, CAS, Beijing 100101, China; \\ weibg@igsnrr.ac.cn (B.W.); yhli@igsnrr.ac.cn (Y.L.); lihr@igsnrr.ac.cn (H.L.) \\ * Correspondence: yebx@chinacdc.cn; Tel.: +86-10-5093-0227; Fax: +86-10-5093-0224
}

Academic Editor: Vincenzo Torretta

Received: 4 January 2017; Accepted: 17 March 2017; Published: 24 March 2017

\begin{abstract}
Urbanization is an inevitable trend in historical development, but eco-environmental problems, including drinking water safety, have gradually become more and more outstanding during the process of rural urbanization. Ten districts in rural areas of Beijing, China were selected to study the effects of urbanization on drinking water quality. The relation between the urbanization index and drinking water quality indicators were explored. The influence of the urbanization process on drinking water quality showed that housing construction, population urbanization, energy consumption, and industrialization during urban development were closely related to drinking water quality. The paired $t$-test showed the total electricity consumption, living electricity consumption, tertiary industry, and the GDP growth rate had boundary $(p=0.06)$ or significantly positive $(p<0.05)$ relations with the qualified rate of rural drinking water. The grey correlation analysis showed that the growth rates of the value-added of housing construction areas were the most important factor affecting comprehensive water quality of Beijing rural areas, followed by the growth rates of the value-added by secondary industry and total electricity consumption, and then the growth rates of the value-added by the tertiary industry and GDP. Urbanization had a significant impact on individual water quality indicators. The results of this study provided some supports for drinking water security in the face of urbanization.
\end{abstract}

Keywords: rural areas; urbanization; drinking water; water quality; grey correlation analysis

\section{Introduction}

With the comprehensive development of society and economy in China, rural urbanization is the inevitable trend of rural development [1]. During rural urbanization, the high-density conglomeration of people, factors of production, and economic activities will produce some environmental problems, such as environmental pollution by industrial and domestic wastewater, gas, and residue [2]. When these contaminant sources are released from a point of entry, they can rapidly spread throughout the water distribution system and worsen the water quality [3,4]. Urban development dramatically alters natural watershed ecosystem structures and functions, and stresses water resources [5]. Water resources and water quality in urban environments around the world are increasingly stressed due to population growth and rapid land use change [6,7]. Regional case studies demonstrate that urbanization could increase levels of coliform bacteria [8,9], heavy metals [10,11], and other water indicators of streams, lakes, and rivers, including dissolved oxygen, chemical oxygen demand, $\mathrm{pH}$, total hardness, and other chemicals [12,13]. In recently years, many studies were carried out on pollution source identification [14-16], early warning of water pollution $[17,18]$, pollutant event 
detection $[19,20]$, and water treatment and disinfection [21,22] to explain the influencing factors of drinking water quality. However, there are seldom studies on the influence of urbanization processes on rural drinking water quality. Any number of water quality measurements can serve as indicators of water quality. However, there is no single measure that can describe the overall water quality for any one body of water. Thus, a multi-index evaluation method that quantifies the extent to which a number of water quality measures deviate from normal concentrations may be more appropriate for summarizing water quality conditions [23]. Although there is no globally-accepted multi-index of water quality, some countries and regions have used, or are using, aggregated water quality data in the development of water quality indices [24-28]. As such, in order to study impacts of rural urbanization on drinking water quality issues, rural areas of Beijing, China were selected as pilot study areas. A multi-index comprehensive evaluation method was used to evaluate drinking water quality of Beijing rural areas. The relation between parameters of urbanization and drinking water quality indicators were explored by the use of gray correlation models.

\section{Materials and Methods}

\subsection{Study Area}

Since the implementation of reform and open policy, the city of Beijing, as the capital of China, has been going through rapid urbanization, and there have been tremendous changes in rural areas of Beijing. Water, as the basis of survival of humans and their surroundings, is impacted by the urbanization of rural areas. Thus, ten rural districts shown in Figure 1 were chosen to explore and study the effects of urbanization on rural drinking water quality in Beijing, China. According to the urban planning of Beijing, Tongzhou, Shunyi, Fangshan, Daxing, and Changping are new urban development districts. Huairou, Pinggu, Mentougou, Miyun, and Yanqing are districts dedicated to ecological conservation.

\subsection{Methods}

\subsubsection{Grey Correlation Analysis}

Grey correlation analysis is employed in this paper to show correlative degrees of various influencing factors of urbanization parameters on drinking water quality of Beijing rural areas from 2009 to 2012. Grey theory is an effective uncertainty knowledge acquisition model proposed by Deng [29]. Grey correlation analysis has drawn more and more researchers' attention in recent years and achieved many research results [30]. Grey correlation analysis quantifies the dynamic correlation degree of the trend of a system and its influencing factors; it is suitable for dynamic analysis [31]. The steps of implementation are as follows: (1) Define a reference number sequence reflecting the system behavior and compare the number sequence affecting the system behavior; (2) Turn the reference and comparing number sequences into dimensionless variables for better comparison of various factors; (3) Calculate the grey correlation coefficient of the reference and comparing number sequences, and determine the maximum and minimum of the grey relational coefficient; (4) Calculate the grey correlation degree $(r)$. We take the urbanization index for the system behavior characteristics of the sequence, the comprehensive index of drinking water quality, or the concentration of individual drinking water quality indicator for related factors. MATLAB (MathWorks, Natick, MA, USA) is used to calculate the grey correlation degree; its value is between 0 and 1 , and the larger the grey correlation degree is, the closer the relationship becomes. 


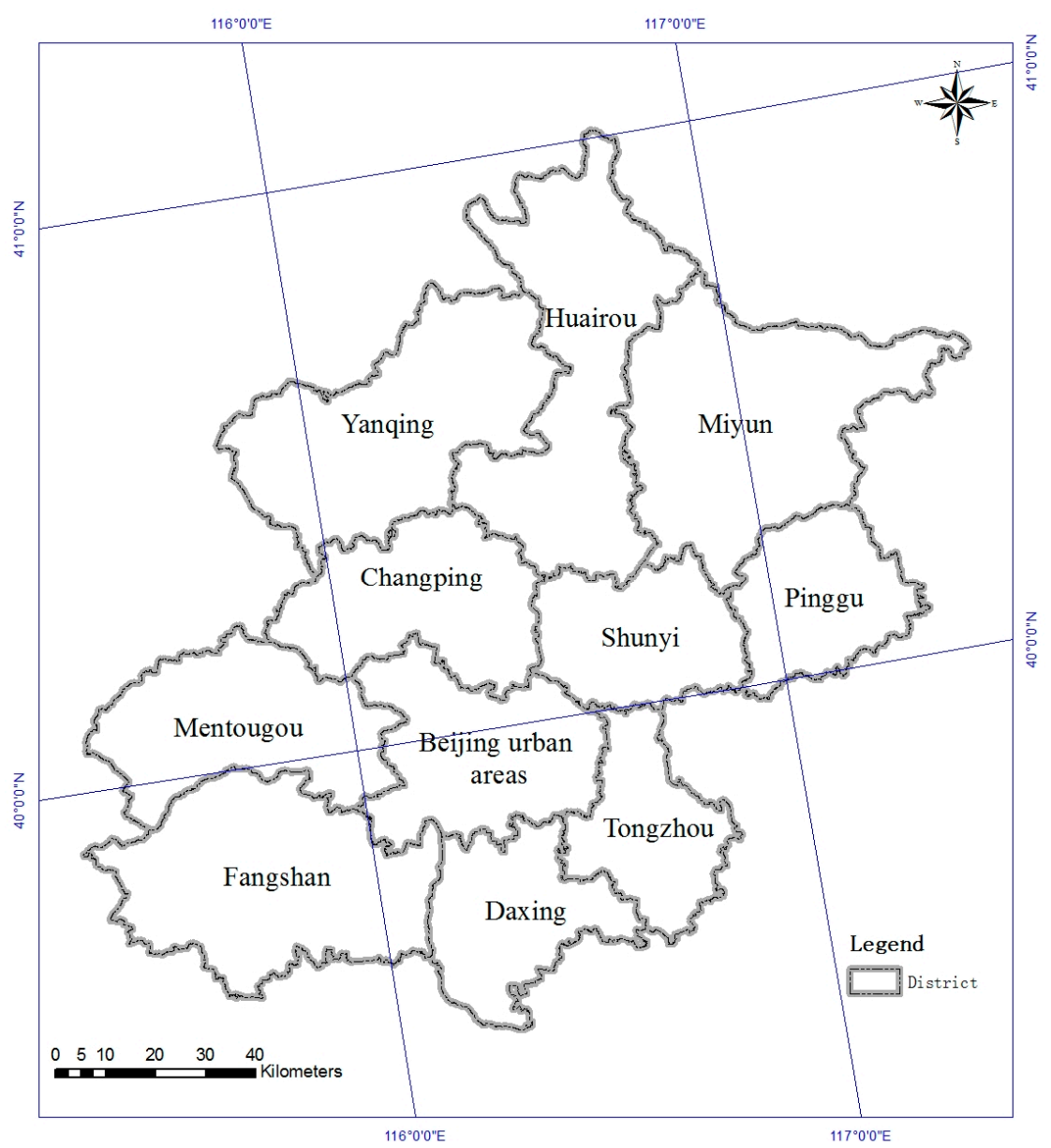

Figure 1. The map of study areas (Beijing urban areas include Dongcheng, Xicheng, Haidian, Chaoyang, Fengtai, and Shijinshan districts).

\subsubsection{Selection of the Index of Urbanization}

With reference to other studies and actual data obtained from Beijing rural areas [32], the ratio of the non-agricultural population to the total population, the gross domestic product (GDP) annual growth rate, the growth rates of value-added by second industry, the growth rates of value-added by tertiary industry, the growth rates of value-added by the housing construction area, the growth rates of the total retail sales of consumer goods, the total electricity consumption, living electricity consumption, the growth rates of per capita disposable income, and the total energy consumption of ten rural districts from 2009 to 2012 were selected to build the index system of urbanization. These indices were analyzed by factor analysis using the principal component method to extract the main factors and determine the factor loadings.

\subsubsection{Evaluation Index System for Drinking Water Quality}

In China, the qualified rate of water quality is commonly used to evaluate drinking water quality. The qualified rate is the percentage of qualified water samples. China's drinking water quality standard is taken as the standard for judging the sample, whether it is qualified or not; in the case where one or more indicators do not meet the standard, the water quality of the sample is unqualified. China's drinking water quality standards includes 106 water quality indicators, but due to the limited detection capacity of water quality indicators in many rural areas only a dozen water quality indicators could be detected and supervised. In this study, 18 water quality indicators, including chroma, turbidity, smell, visible substance, $\mathrm{pH}$, total hardness, iron $(\mathrm{Fe})$, manganese $(\mathrm{Mn})$, sulfate $\left(\mathrm{SO}_{4}{ }^{2-}\right)$, chloride 
$\left(\mathrm{Cl}^{-}\right)$, total dissolved solids (TDS), oxygen consumption $\left(\mathrm{COD}_{\mathrm{Mn}}\right)$, total hardness $\left(\mathrm{CaCO}_{3}\right)$, ammonia nitrogen $\left(\mathrm{NH}_{4}{ }^{+}\right)$, arsenic (As), fluoride $\left(\mathrm{F}^{-}\right)$, nitrate $\left(\mathrm{NO}_{3}{ }^{-}\right)$, total coliform (TC), and total bacterial count (TBC) of ten rural districts from 2009 to 2012 were selected to evaluate drinking water safety. All of these water quality indicators data were from the results of water samples in 10 rural areas during 2009-2012, which were detected by the methods according to "Standard examination methods for drinking water (GB5750-2006)" [33]. Chroma, turbidity, smell, visible substance, $\mathrm{pH}, \mathrm{CaCO}_{3}, \mathrm{Fe}$, $\mathrm{Mn}, \mathrm{SO}_{4}{ }^{2-}, \mathrm{Cl}^{-}$, TSD, $\mathrm{COD}_{\mathrm{Mn}}$, total hardness, and $\mathrm{NH}_{4}{ }^{+}$are classified as organoleptic characteristics and general chemical indices. Arsenic, $\mathrm{F}^{-}$and $\mathrm{NO}_{3}{ }^{-}$are classified as toxicology indicators. TC and TBC are classified as microbiological indicators.

Use of the water quality qualified rate to explore the relationship between the urbanization process and the safety of drinking water may result in some information being missing, and some conclusions could not match with the actual results. Therefore, it is necessary to evaluate drinking water with a more comprehensive evaluation index system, and analyze the relationship between urbanization and drinking water quality by this system. In this study, a multi-index comprehensive evaluation method was also used to evaluate water quality conditions. This method, as a relatively traditional method of environmental assessment, has the advantage of simple calculation, clear meaning and flexibility [34], and could quantitatively and comprehensively describe drinking water quality [35]. It is a suitable method for the assessment of a water quality index. The performance of 18 water quality indicators was compared by this method with the formula:

$$
W Q I_{j}=\sqrt{\frac{I_{i, \text { average }^{2}+I_{i, \text { max }^{2}}}}{2}}
$$

where $W Q I_{j}$ is the comprehensive index of drinking water quality indicators from 1 to $j . I_{i}$ is the index of drinking water indicator $i . I_{i}=C_{i} / S_{i}, C_{i}$ is the measured concentration of drinking water indicator $i$, $S_{i}$ is the value of indicator $i$ in China's drinking water quality standards. $I_{i, \text { average }}$ and $I_{i, \max }$ indicated the mean value and maximum value of all indices, respectively. In addition, when the concentration of TC is below the drinking water standard, the $I_{\mathrm{TC}}$ is defined as 1 , but when its value exceeds the drinking water standard, $I_{\mathrm{TC}}=1+\lg \left(C_{i} / 0.3\right)$; when the concentration of $\mathrm{TBC}$ is below the drinking water standard, the $I_{T B C}$ is defined as 1 , but when its value exceeds the drinking water standard, $I_{\mathrm{TBC}}=1+\lg \left(C_{i} / 100\right)$; when the $\mathrm{pH}$ value is within the drinking water standard limit, the $I_{\mathrm{pH}}$ is defined as 0.1 , but when its value exceeds the drinking water standard, $I_{\mathrm{pH}}=\left(C_{i}-7.5\right) /(8.5$ or $6.5-7.5)$; for other water quality indicators, when $C_{i} / S_{i}<0.1$, or the measured value is lower than the minimum detectable value, $I_{i}$ is defined as 0.10 [36].

\section{Results}

\subsection{The Index System of Urbanization}

The results of factor analysis of indices of urbanization are shown in Table 1; five factors were extracted and the cumulative contribution of variances was $81.870 \%$. The first factor accounted for $28.197 \%$ and its loadings on total electricity consumption, living electricity consumption, and total energy consumption are positive and relatively significant. The second factor accounted for $21.566 \%$ and its loadings on GDP annual growth rate, the growth rates of value-added of secondary industries, and the growth rates of value-added of tertiary industries are positive and relatively significant. The loading of the third factor on the growth rates of the total retail sales of consumer goods is positive and relatively significant, but the loading on the ratio of the non-agricultural population to the total population is negative, and the absolute value is significant. The fourth factor had high and positive loading on the growth rates of the per capita disposable income, and the fifth factor had high and positive loading on the growth rates of value-added of housing construction areas; both of them are relatively significant. 
Table 1. The loadings of index of urbanization.

\begin{tabular}{|c|c|c|c|c|c|}
\hline Urbanization Parameters & Factor 1 & Factor 2 & Factor 3 & Factor 4 & Factor 5 \\
\hline Total electricity consumption & 0.985 & 0.072 & 0.008 & 0.051 & -0.062 \\
\hline Living electricity consumption & 0.889 & -0.057 & -0.155 & 0.075 & -0.092 \\
\hline The ratio of non-agricultural population to total population & 0.104 & -0.287 & -0.709 & 0.288 & 0.322 \\
\hline The growth rates of the total retail sales of consumer goods & 0.109 & -0.035 & 0.820 & 0.302 & 0.209 \\
\hline The growth rates of the per capita disposable income & 0.073 & 0.059 & 0.073 & 0.858 & 0.067 \\
\hline GDP annual growth rate & 0.125 & 0.958 & 0.092 & 0.080 & 0.125 \\
\hline The growth rates of value-added of secondary industries & 0.111 & 0.809 & 0.137 & -0.184 & 0.329 \\
\hline The growth rates of value-added of tertiary industries & -0.020 & 0.666 & -0.049 & 0.417 & -0.295 \\
\hline The growth rates of value-added of housing construction areas & -0.174 & 0.171 & 0.002 & 0.060 & 0.836 \\
\hline Total energy consumption & 0.814 & 0.210 & 0.217 & -0.007 & -0.043 \\
\hline Eigenvalues & 2.820 & 2.157 & 1.169 & 1.105 & 0.937 \\
\hline$\%$ of variances & 28.197 & 21.566 & 11.691 & 11.047 & 9.369 \\
\hline Cumulative \% & 28.197 & 49.762 & 61.454 & 72.500 & 81.870 \\
\hline
\end{tabular}

\subsection{The Comprehensive Index of Drinking Water Quality Indicators}

The mean value of the comprehensive water quality index of Beijing rural areas from 2009 to 2012 are shown in Table 2. The results show that the WQI value was highest in Yanqing, Chanping, and Mentougou districts, followed by Huairou, Miyun, and Shunyi districts. The value of Pinggu district was the lowest.

Table 2. The comprehensive index of water quality of Beijing rural areas.

\begin{tabular}{|c|c|c|c|c|c|c|c|c|c|c|}
\hline & $C P^{1}$ & $\mathrm{DX}^{1}$ & FS $^{1}$ & $\mathrm{HR}^{1}$ & MTG $^{1}$ & MY $^{1}$ & $\mathrm{PG}^{1}$ & $S Y^{1}$ & $\mathrm{TZ}^{1}$ & $\mathrm{YQ}^{1}$ \\
\hline$I_{\text {chroma }}$ & 0.86 & 0.72 & 0.76 & 0.94 & 0.79 & 0.70 & 0.77 & 1.03 & 0.78 & 0.98 \\
\hline$I_{\text {turbidity }}$ & 0.65 & 0.68 & 0.59 & 0.92 & 1.27 & 0.63 & 0.69 & 0.93 & 0.72 & 0.64 \\
\hline$I_{\mathrm{pH}}$ & 0.40 & 0.41 & 0.41 & 0.48 & 0.44 & 0.56 & 0.42 & 0.40 & 0.41 & 0.42 \\
\hline$I_{\mathrm{CaCO} 3}$ & 0.42 & 0.52 & 0.55 & 0.41 & 0.47 & 0.44 & 0.36 & 0.60 & 0.40 & 0.40 \\
\hline$I_{\mathrm{Fe}}$ & 0.25 & 0.23 & 0.20 & 0.30 & 0.29 & 0.24 & 0.38 & 0.38 & 0.51 & 0.21 \\
\hline$I_{\mathrm{Mn}}$ & 0.33 & 0.22 & 0.46 & 0.52 & 0.50 & 0.56 & 0.55 & 0.43 & 0.48 & 0.47 \\
\hline$I_{\mathrm{SO} 4}{ }^{2-}$ & 0.28 & 0.34 & 0.38 & 0.28 & 0.41 & 0.31 & 0.24 & 0.41 & 0.37 & 0.24 \\
\hline$I_{\mathrm{Cl}^{-}}^{-}$ & 0.17 & 0.31 & 0.23 & 0.17 & 0.69 & 0.21 & 0.24 & 0.27 & 0.20 & 0.21 \\
\hline$I_{\text {smell }}$ & 0.10 & 0.10 & 0.10 & 0.10 & 0.10 & 0.10 & 0.10 & 0.10 & 0.10 & 0.10 \\
\hline$I_{\text {visible substance }}$ & 0.10 & 0.10 & 0.14 & 0.10 & 0.11 & 0.10 & 0.10 & 0.10 & 0.10 & 0.10 \\
\hline$I_{\mathrm{STD}}$ & 0.25 & 0.34 & 0.36 & 0.23 & 0.33 & 0.30 & 0.23 & 0.24 & 0.28 & 0.22 \\
\hline$I_{\mathrm{CODMn}}$ & 0.23 & 0.22 & 0.18 & 0.21 & 0.28 & 0.31 & 0.25 & 0.19 & 0.36 & 0.30 \\
\hline $\mathrm{I}_{\mathrm{NH} 4}{ }^{+}$ & 0.15 & 0.11 & 0.15 & 0.16 & 0.27 & 0.15 & 0.23 & 0.28 & 0.43 & 0.37 \\
\hline$I_{\mathrm{As}}$ & 0.21 & 0.13 & 0.15 & 0.11 & 0.12 & 0.11 & 0.10 & 0.46 & 0.28 & 0.17 \\
\hline$I_{\mathrm{F}}^{-}$ & 0.26 & 0.29 & 0.24 & 0.22 & 0.30 & 0.18 & 0.33 & 0.40 & 0.41 & 0.28 \\
\hline$I_{\mathrm{NO} 3}$ & 0.45 & 0.54 & 0.71 & 0.57 & 0.51 & 0.69 & 0.39 & 0.29 & 0.19 & 0.34 \\
\hline$I_{\mathrm{TC}}$ & 1.47 & 0.91 & 1.10 & 1.40 & 1.13 & 0.91 & 0.91 & 0.87 & 0.77 & 1.62 \\
\hline$I_{\mathrm{TBC}}$ & 0.74 & 0.77 & 0.74 & 0.79 & 0.79 & 1.22 & 0.73 & 0.73 & 0.78 & 1.05 \\
\hline$I_{\text {average }}$ & 0.43 & 0.40 & 0.43 & 0.46 & 0.51 & 0.44 & 0.41 & 0.47 & 0.44 & 0.47 \\
\hline$I_{\max }$ & 1.91 & 1.35 & 1.47 & 1.80 & 2.15 & 1.90 & 1.27 & 1.80 & 1.22 & 2.35 \\
\hline$W Q I$ & 1.10 & 0.78 & 0.83 & 1.05 & 1.09 & 1.02 & 0.68 & 1.05 & 0.76 & 1.35 \\
\hline
\end{tabular}

${ }^{1}$ CP: Changping, DX: Daxing, FS: Fangshan, HR: Huairou, MTG: Mentougou, MY: Miyun, PG: Pinggu, SY: Shunyi, TZ: Tongzhou, YQ: Yanqing.

\subsection{Relationship between the Qualified Rate of Water Quality and the Urbanization Index}

The paired $t$-test was used to analyze the relation between the urbanization index and the qualified rate of water quality. The results are shown in Table 3. The total electricity consumption and living electricity consumption had a boundary positive relation with the qualified rate of water quality $(p=0.06)$; the relation between the GDP annual growth rate and the water quality qualified rate is a significantly positive correlation $(p<0.05)$, and there is boundary positive correlation between the growth rates of the value-added by tertiary industries and the water quality qualified rate $(p=0.06)$. 
Table 3. Paired $t$-test for the urbanization index and the qualified rate of drinking water quality.

\begin{tabular}{clccc}
\hline & & $N$ & Correlation $(\boldsymbol{R})$ & Sig. $(p)$ \\
\hline Pair 1 & Total electricity consumption and qualify rate of drinking water & 40 & 0.349 & 0.059 \\
\hline Pair 2 & Living electricity consumption and qualify rate of drinking water & 40 & 0.353 & 0.056 \\
\hline Pair 3 & $\begin{array}{l}\text { The ratio of non-agricultural population to total population and } \\
\text { qualify rate of drinking water }\end{array}$ & 40 & 0.054 & 0.778 \\
\hline Pair 4 & $\begin{array}{l}\text { The growth rates of the total retail sales of consumer goods and } \\
\text { qualify rate of drinking water }\end{array}$ & 40 & 0.188 & 0.320 \\
\hline Pair 5 & $\begin{array}{l}\text { The growth rates of the per capita disposable income and qualify } \\
\text { rate of drinking water }\end{array}$ & 40 & -0.287 & 0.124 \\
\hline Pair 6 & GDP annual growth rate and qualify rate of drinking water & 40 & 0.404 & 0.027 \\
\hline Pair 7 & $\begin{array}{l}\text { The growth rates of value-added of the second industry and } \\
\text { qualify rate of drinking water }\end{array}$ & 40 & 0.248 & 0.186 \\
\hline Pair 8 & $\begin{array}{l}\text { The growth rates of value-added of the tertiary industry and } \\
\text { qualify rate of drinking water }\end{array}$ & 40 & 0.344 & 0.063 \\
\hline Pair 9 & $\begin{array}{l}\text { The growth rates of value-added of housing construction area } \\
\text { and qualify rate of drinking water }\end{array}$ & 40 & -0.160 & 0.399 \\
\hline Pair 10 & Total energy consumption and qualify rate of drinking water & 40 & 0.291 & 0.119 \\
\hline
\end{tabular}

\subsection{Relationship between the Comprehensive Evaluation Index of Drinking Water and the Urbanization Index}

Grey relational analysis was used to comprehensively analyze the correlation between the level of urbanization and the comprehensive index of drinking water quality in Beijing rural areas. The results are shown in Table 4. The correlation degrees of the Beijing urbanization index and the comprehensive index of drinking water quality were in the following order: the primary driving factors were the growth rates of the value-added by housing construction areas, followed by the growth rates of the value-added by the secondary industries and the total electricity consumption, followed by the growth rates of the value-added by the tertiary industries and the GDP annual growth rate.

Table 4. The gray correlation between urbanization index and comprehensive water quality index.

\begin{tabular}{lc}
\hline \multicolumn{1}{c}{ Urbanization Index } & Gray Correlative Degrees $(\boldsymbol{r})$ \\
\hline The growth rates of value-added of housing construction area & 0.455 \\
The growth rates of value-added of the second industry & 0.414 \\
Total electricity consumption & 0.414 \\
The growth rates of value-added of the tertiary industry & 0.405 \\
GDP annual growth rate & 0.393 \\
Living electricity consumption & 0.392 \\
Total energy consumption & 0.388 \\
The growth rates of the total retail sales of consumer goods & 0.387 \\
The growth rates of the per capita disposable income & 0.375 \\
The ratio of non-agricultural population to total population & 0.350 \\
\hline
\end{tabular}

\subsection{Correlation between Microbiological and Toxicology Indicators of Drinking Water and the} Urbanization Index

The correlation between microbiological and toxicology indicators of drinking water and the urbanization index were also analyzed by grey relational analysis. The results are shown in Table 5 . As microbiological indicators, TC and TBC have high relation with the growth rates of the value-added by housing construction areas, the ratio of the non-agricultural population to the total population, and the growth rates of value-added by the secondary industries. With respect to toxicology indicators, arsenic and $\mathrm{NO}_{3}{ }^{-}$are highly impacted by the growth rates of the value-added by housing construction areas and the GDP annual growth rate. However, $\mathrm{F}^{-}$is mainly affected by total energy consumption, GDP annual growth rate, and the growth rates of the value-added by the secondary industries. 
Table 5. Gray correlative degrees of the urbanization index on the microbiological indicator and the toxicology indicator of drinking water quality.

\begin{tabular}{|c|c|c|c|c|c|}
\hline Urbanization Index & As & $\mathbf{F}^{-}$ & $\mathrm{NO}_{3}{ }^{-}$ & TC & ТВС \\
\hline Total electricity consumption & 0.390 & 0.445 & 0.384 & 0.364 & 0.394 \\
\hline Living electricity consumption & 0.431 & 0.465 & 0.361 & 0.396 & 0.426 \\
\hline The ratio of non-agricultural Population to total population & 0.544 & 0.406 & 0.448 & 0.620 & 0.595 \\
\hline The growth rates of the total retail Sales of consumer goods & 0.457 & 0.440 & 0.442 & 0.415 & 0.476 \\
\hline The growth rates of the per capita Disposable income & 0.422 & 0.348 & 0.469 & 0.454 & 0.493 \\
\hline GDP annual growth rate & 0.510 & 0.551 & 0.491 & 0.477 & 0.550 \\
\hline The growth rates of value-added of The second industry & 0.508 & 0.520 & 0.423 & 0.502 & 0.579 \\
\hline The growth rates of value-added of The tertiary industry & 0.509 & 0.443 & 0.476 & 0.489 & 0.559 \\
\hline The growth rates of value-added of Housing construction area & 0.591 & 0.394 & 0.538 & 0.530 & 0.599 \\
\hline Total energy consumption & 0.514 & 0.558 & 0.442 & 0.501 & 0.510 \\
\hline
\end{tabular}

3.6. Correlation between the Organoleptic Characters and General Chemical Index of Drinking Water and the Urbanization Index

The correlation between the organoleptic characters and general chemical index of drinking water and the urbanization index were also analyzed by gray correlation analysis. The results are shown in Table 6 . The growth rates of value-added by housing construction areas have significant relation with chromaticity, iron, sulfate, chloride, TDS, $\mathrm{COD}_{\mathrm{Mn}}, \mathrm{pH}$, and total hardness. Chroma, turbidity, and total hardness have close relations with the ratio of the non-agricultural population to the total population. The growth rates of the value-added by the secondary industries are closely related to $\mathrm{COD}_{\mathrm{Mn}}, \mathrm{pH}$, turbidity, $\mathrm{Fe}, \mathrm{Mn}$, and $\mathrm{NH}_{4}{ }^{+}$.

Table 6. Gray correlative degrees of urbanization index on organoleptic characters and the general chemical index.

\begin{tabular}{|c|c|c|c|c|c|c|c|c|c|c|c|}
\hline $\begin{array}{l}\text { Urbanization } \\
\text { Index }\end{array}$ & Chroma & Turbidity & $\mathrm{Fe}$ & Mn & $\mathrm{SO}_{4}{ }^{2-}$ & $\mathrm{Cl}^{-}$ & TDS & $\mathrm{COD}_{\mathrm{Mn}}$ & $\mathrm{pH}$ & $\mathrm{CaCO}_{3}$ & $\mathrm{NH}_{4}{ }^{+}$ \\
\hline $\begin{array}{l}\text { Total electricity } \\
\text { consumption }\end{array}$ & 0.422 & 0.390 & 0.346 & 0.318 & 0.543 & 0.553 & 0.518 & 0.351 & 0.459 & 0.423 & 0.410 \\
\hline $\begin{array}{l}\text { Living electricity } \\
\text { consumption }\end{array}$ & 0.423 & 0.411 & 0.377 & 0.346 & 0.462 & 0.491 & 0.475 & 0.371 & 0.441 & 0.392 & 0.470 \\
\hline $\begin{array}{c}\text { The ratio of } \\
\text { non-agricultural } \\
\text { Population to total } \\
\text { population }\end{array}$ & 0.518 & 0.568 & 0.430 & 0.378 & 0.484 & 0.512 & 0.499 & 0.460 & 0.395 & 0.507 & 0.433 \\
\hline $\begin{array}{l}\text { The growth rates } \\
\text { of the total Retail } \\
\text { sales of consumer } \\
\text { goods }\end{array}$ & 0.447 & 0.481 & 0.417 & 0.409 & 0.493 & 0.489 & 0.459 & 0.402 & 0.365 & 0.452 & 0.417 \\
\hline $\begin{array}{l}\text { The growth rates } \\
\text { of the per Capita } \\
\text { disposable income }\end{array}$ & 0.424 & 0.412 & 0.451 & 0.369 & 0.473 & 0.464 & 0.475 & 0.437 & 0.425 & 0.451 & 0.372 \\
\hline $\begin{array}{l}\text { GDP annual } \\
\text { growth rate }\end{array}$ & 0.507 & 0.536 & 0.467 & 0.443 & 0.463 & 0.478 & 0.523 & 0.472 & 0.413 & 0.490 & 0.411 \\
\hline $\begin{array}{l}\text { The growth rates } \\
\text { of value-added by } \\
\text { the secondary } \\
\text { industries }\end{array}$ & 0.475 & 0.529 & 0.459 & 0.466 & 0.437 & 0.450 & 0.470 & 0.529 & 0.448 & 0.433 & 0.454 \\
\hline $\begin{array}{l}\text { The growth rates } \\
\text { of the value-added } \\
\text { by the tertiary } \\
\text { industries }\end{array}$ & 0.480 & 0.482 & 0.460 & 0.387 & 0.482 & 0.507 & 0.511 & 0.466 & 0.386 & 0.491 & 0.416 \\
\hline $\begin{array}{c}\text { The growth rates } \\
\text { of value-added of } \\
\text { housing } \\
\text { construction areas }\end{array}$ & 0.543 & 0.506 & 0.485 & 0.348 & 0.555 & 0.587 & 0.564 & 0.491 & 0.458 & 0.490 & 0.445 \\
\hline $\begin{array}{l}\text { Total energy } \\
\text { consumption }\end{array}$ & 0.553 & 0.507 & 0.413 & 0.345 & 0.480 & 0.546 & 0.531 & 0.431 & 0.431 & 0.476 & 0.463 \\
\hline
\end{tabular}




\section{Discussion}

\subsection{Urbanization Index and Comprehensive Water Quality}

Rural urbanization is a representation of the translation of the society-economy structure; that is, economic activities translating from primary industries to the secondary and tertiary industries, and rural consumption style translating to urban style [37]. The results of factor analysis of the urbanization indices showed that factor 1 reflected the impact of energy consumption on the process of urbanization. The higher the score of the first factor, the greater the consumption of total electricity, living electricity, and total energy. Factor 1 was defined as energy consumption. Factor 2 reflected the relation between economy and town, and was defined as the industry structure. Rural urbanization is also a process of the rural population transferring to the urban regions [37]. This process results in the increase of the total population and total retail sales of consumer goods in the town. Factor 3 showed that the higher the score of third factor, the larger the total population becomes, and then the more total retail sales of consumer goods are, and the lower the ratio of the non-agricultural population to the total population is. Factor 3 was defined as the population structure. Rural urbanization could broaden the employment methods and increase their income [32]. Factor 4 reflected the impact of disposable income and was defined as income. Rural urbanization is also a process of the rural community becoming an urban community that increases the growth of housing construction [32]. Factor 5 showed that the higher the score of the fifth factor, the greater the growth rates of the value-added by housing construction areas, and was defined as land change.

The results of the multi-index comprehensive evaluation of drinking water showed that the comprehensive water quality of the rural areas west and south of Beijing was better than that of those to the east and north. The individual drinking water quality indicator was different from district to district. The quality of microbiological indicators was better in the south of Beijing than in the north. The quality of toxicology indicators was good in all Beijing rural areas and the level of indicators was lower than the standard limit.

\subsection{Relationship between the Comprehensive Water Quality and Urbanization Index}

The relation between the qualified rate of water quality and the urbanization index show that urbanization factors of energy consumption, economic development, and industrial structure had significant influences on rural drinking water. These factors illustrate the higher urbanization of the higher water quality qualified rate. China's rapid urbanization has been accompanied by economic growth and transformation. With the rapid development of the economy and the improvement of the level of urbanization, the government and enterprises have increased the construction of water utilities [38], introduced advanced water treatment processes [38], and strengthened the protection of water environment of consciousness and planning [38,39]; thus, the water quality qualified rate is correspondingly improved.

The gray relation between the comprehensive water quality index and the urbanization index shows that the factors influencing drinking water quality are mainly embodied in the land change and industrial structure changes, energy consumption, and economic development. The growth rates of the value-added by housing construction areas account for the primary driving factor, which shows that housing construction has the greatest impact on rural drinking water quality. An increase in the housing construction areas causes the land use/land cover change (LUCC), which has vital significance in environmental variation, such as water, air, and soil environmental variation [40]. The factors of the growth of the secondary and tertiary industries, total electricity consumption, and GDP reflect that the effect of urbanization is large with respect to economic development and energy consumption on rural drinking water quality. Rural urbanization is the translation of society-economy structure, lifestyle, and conception - the translating of the rural lifestyle to an urban lifestyle [37]. These factors reduced the pollution of agriculture, but led to an increase of water pollution and solid waste emission. The ratio of the non-agricultural population to the total population, the growth rates of the total retail 
sales of consumer goods, and the growth rates of per capita disposable income have not had high relation with the comprehensive evaluation index of water quality, indicating that there were only small changes of the total population, resident's social consumption, and income in Beijing rural areas from 2009 to 2012. Thus, these urbanization indices only have a slight impact on the comprehensive rural drinking water quality.

\subsection{Relationship between the Individual Water Quality Indicator and the Urbanization Index}

The results of gray correlation between microbiological and toxicology indicators of drinking water and the urbanization index showed that TC and TBC were mainly affected by the growth rates of housing construction area and population urbanization. This indicates that the population structure and land use change in the urbanization process has a significant influence on microbiological indicators in rural drinking water. Additionally, nitrate and arsenic were also mainly affected by the growth rates of the value-added by housing construction areas. With the development of the real estate and housing construction, many farmland, forest, and mountains change to residential or commercial buildings [41]. This impacts the farmland tillage and use of fertilizer and farm manure, which, in turn, affects TC, TBC, arsenic, and nitrate in rural drinking water [42]. The fluoride was mainly affected by secondary industries. The main reason is the manufacturing of fluorine-containing products, coke production, electronic component production, electroplating, and silicate glass production, which discharge industrial wastewater containing fluoride.

The results of gray correlation between the organoleptic characters and the general chemical index of drinking water and the urbanization index reveal that the growth rates of value-added by housing construction areas, the non-agricultural population, GDP, and secondary industries have large influences on the organoleptic characters and general chemical index, which further reflects the influence of land use change in the urbanization process on various water quality indices, and it also shows that economic growth is a key factor resulting in the changes of many water quality indicators in the urbanization process. The $\mathrm{pH}, \mathrm{COD}_{\mathrm{Mn}}$ turbidity, $\mathrm{Fe}, \mathrm{Mn}$, and $\mathrm{NH}_{4}{ }^{+}$values were highly impacted by the growth rates of the value-added by the secondary industries. With the development of secondary industries, residents' lifestyles have changed accordingly $[43,44]$. For example, they could easily buy and use detergents and cleaning supplies, and these could change the $\mathrm{pH}, \mathrm{COD}_{\mathrm{Mn}}$, and $\mathrm{NH}_{4}{ }^{+}$in drinking water. With the rapid development of iron and steel products, the discharge of wastewater, comprised of iron and manganese, appears to be serious. All of these further illustrate that the industrial structure changes are key factors in the urbanization process which affects the drinking water quality.

\section{Conclusions}

The effects of urbanization processes on water quality show that land use and industry structure change, energy consumption, and population structure change during rural urbanization have important influences on rural drinking water safety. In Beijing rural areas, the qualified rate of rural drinking water have boundaries or significant positive relations with the urbanization parameters, such as total electricity consumption, living electricity consumption, the tertiary industry growth rate, and GDP annual growth rate. There are high relations between the Beijing rural urbanization level and the comprehensive water quality index, and the comprehensive water quality index is closely related to the factors of the growth rates of the value-added by housing construction areas, the secondary and tertiary industries, GDP annual growth rate, and the total electricity consumption. As individual drinking water quality indicators, TC and TBC were mainly affected by the growth rates of housing construction areas and population urbanization; arsenic and $\mathrm{NO}_{3}{ }^{-}$were also highly impacted by the growth rates of the value-added by housing construction areas and the GDP annual growth rate; the fluoride level was closely related to the growth of secondary industries and energy consumption. The growth of GDP, land use change, population urbanization, and the development of secondary industries have large influences on the organoleptic characters and the general chemical index. 
Thus, in order to ensure rural drinking water safety, it is of great significance to increase economic development and control the growth rate of real estate development and housing construction. It is also important to restrain the pollution of the environment along with the readjustment of industrial structures. Reducing energy consumption and using clean energy are the main measures to improve rural drinking water quality.

Acknowledgments: This research was financially supported by the research plans of the National Science Foundation of China (No. 41171085). This research was partly supported by the Major Science and Technology Project of Water Pollution Control and Management in China (No. 2014ZX07405001).

Author Contributions: Lan Zhang and Bixiong Ye conceived the research idea and co-wrote the paper. Shenghua Gao conducted the model simulations and data analysis. Binggan Wei and Yonghua Li revised the paper. Hairong Li conducted the model simulations. Li Wang conducted the data analysis.

Conflicts of Interest: The authors declare no conflict of interest.

\section{References}

1. Ma, H.L.; Shi, C.L.; Chou, N.T. China's Water Utilization Efficiency: An Analysis with Environmental Considerations. Sustainability 2016, 8, 516. [CrossRef]

2. Zoebl, D. Is Water Productivity a Useful Concept in Agricultural Water Management? Agric. Water Manag. 2006, 84, 265-273. [CrossRef]

3. Di Cristo, C.; Leopardi, A. Pollution source identification of accidental contamination in water distribution networks. J. Water Resour. Plan. Manag. 2008, 134, 197-202. [CrossRef]

4. Preis, A.; Ostfeld, A. Contamination source identification in water systems: A hybrid model trees-linear programming scheme. J. Water Resour. Plan. Manag. 2006, 132, 263-273. [CrossRef]

5. Sun, G.; Lockaby, B.G. Urban-Rural Interfaces: Linking People and Nature; Laband, D.N., Lockaby, B.G., Zipperer, W., Eds.; American Society of Agronomy/Soil Science Society of America/Crop Science Society of America: Madison, WI, USA, 2012; Chapter 3; pp. 29-48.

6. Foley, J.A.; DeFries, R.; Asner, G.P.; Barford, C.; Bonan, G.; Carpenter, S.R.; Chapin, F.S.; Coe, M.T.; Daily, G.C.; Gibbs, H.K.; et al. Global consequences of land use. Science 2005, 309, 570-574. [CrossRef] [PubMed]

7. Postel, S.L.; Thompson, B.H. Watershed protection: Capturing the benefits of nature's water supply services. Nat. Resour. Forum 2005, 29, 98-108. [CrossRef]

8. Mashiatullah, A.; Chaudhary, M.Z.; Khan, M.S.; Javed, T.; Qureshi, R.M. Coliform bacterial pollution in Rawal lake, Islamabad and its feeding streams/river. Nucleus 2010, 47, 35-40.

9. Saeed, A.; Hashmi, I. Evaluation of anthropogenic effects on water quality and bacterial diversity in Rawal Lake, Islamabad. Environ. Monit. Assess. 2014, 186, 2785-2793. [CrossRef] [PubMed]

10. Goher, M.E.; Hassan, A.M.; Abdel-Moniem, I.A.; Fahmy, A.H.; El-Sayed, S.M. Evaluation of surface water quality and heavy metal indices of Ismailia canal, Nile river, Egypt. Egypt. J. Aquat. Res. 2014, 40, 225-233. [CrossRef]

11. Nazeer, S.; Hashmi, M.Z.; Malik, R.N. Heavy metals distribution, risk assessment and water quality characterization by water quality index of the river Soan, Pakistan. Ecol. Indic. 2014, 43, 262-270. [CrossRef]

12. Arthur, G.D.; Aremu, A.O.; Moyo, M.; Stirk, W.A.; Staden, J.V. Growth-promoting effects of a seaweed concentrate at various $\mathrm{pH}$ and water hardness conditions. S. Afr. J. Sci. 2012, 109, 1-6. [CrossRef]

13. Kandhro, A.J.; Rind, A.M.; Mastoi, A.A.; Almani, K.F.; Meghwar, S.; Laghari, M.A.; Rajpout, M.S. Physico-chemical assessment of surface and ground water for drinking purpose in Nawabshah city, Sindh, Pakistan. Am. J. Environ. Prot. 2015, 41, 62-69. [CrossRef]

14. Di Cristo, C.; Leopardi, A. Closure to "Pollution source identification of accidental contamination in water distribution networks". J. Water Resour. Plan. Manag. 2010, 136, 292-294. [CrossRef]

15. Tryby, M.E.; Propato, M.; Ranjithan, S.R. Monitoring design for source identification in water distribution systems. J. Water Resour. Plan. Manag. 2010, 136, 637-646. [CrossRef]

16. Banik, B.K.; Cristo, C.D.; Leopardi, A.; Marinis, G.D. Illicit intrusion characterization in sewer systems. Urban Water J. 2016. [CrossRef]

17. Cozzolino, L.; Della Morte, R.; Palumbo, A.; Pianese, D. Stochastic approaches for sensors placement against intentional contaminations in water distribution systems. Civ. Eng. Environ. Syst. 2011, 28, 75-98. [CrossRef] 
18. Edthofer, F.; Van den Broeke, J.; Ettl, J.; Lettl, W.; Weingarthner, A. Reliable online water quality monitoring as basis for fault tolerant control. In Proceedings of the Control and Fault-Tolerant Systems (SysTol), Nice, France, 6-8 October 2010; pp. 57-62.

19. Qin, X.; Gao, F.; Chen, G. Wastewater quality monitoring system using sensor fusion and machine learning techniques. Water Res. 2012, 46, 1133-1144. [CrossRef] [PubMed]

20. Housh, M.; Ostfeld, A. An integrated logit model for contamination event detection in water distribution systems. Water Res. 2015, 75, 210-223. [CrossRef] [PubMed]

21. Idornigie, E.; Templeton, M.R.; Maksimovic, C.; Sharifan, S. The impact of variable hydraulic operation of water distribution networks on disinfection by-products concentrations. Urban Water J. 2010, 7, 301-307. [CrossRef]

22. Di Cristo, C.; Leopardi, A.; de Marinis, G. Assessing measurement uncertainty on trihalomethanes prediction through kinetic models in water supply systems. J. Water Supply Res. Technol. AQUA 2015, 64, 516-528. [CrossRef]

23. UNEP GEMS/Water Programme. Global Drinking Water Quality Index Development and Sensitivity Analysis Report; National Water Research Institute: Burlington, ON, Canada, 2007. Available online: http: //101.96.8.164/www.un.org/waterforlifedecade/pdf/global_drinking_water_quality_index.pdf (accessed on 28 February 2017).

24. Pesce, S.F.; Wunderlin, D.A. Use of water quality indices to verify the impact of Cordoba City (Argentina) on Suquia River. Water Res. 2000, 34, 2915-2926. [CrossRef]

25. Liou, S.M.; Lo, S.L.; Wang, S.H. A generalised water quality index for Taiwan. Environ. Monit. Assess. 2004, 96, 35-52. [CrossRef] [PubMed]

26. Sargaonkar, A.; Deshpande, V. Development of an overall index of pollution for surface water based on a general classification scheme in Indian context. Environ. Monit. Assess. 2003, 89, 43-67. [CrossRef] [PubMed]

27. Stambuk-Giljanovik, N. Comparison of Dalmation water evaluation indices. Water Environ. Res. 2003, 75, 388-405. [CrossRef]

28. Tsegaye, T.; Sheppard, D.; Islam, K.R.; Johnson, A.; Tadesse, W.; Atalay, A.; Marzen, L. Development of chemical index as a measure of in-stream water quality in response to land-use and land cover changes. Water Air Soil Pollut. 2006, 174, 161-179. [CrossRef]

29. Deng, J.L. Introduction to Grey System. J. Grey Syst. 1989, 1, 1-24.

30. Dai, J.; Liu, X.; Hu, F. Research and Application for Grey Relational Analysis in Multigranularity Based on Normality Grey Number. Sci. World J. 2014, 2014, 312645. [CrossRef] [PubMed]

31. Qian, M.X.; Ren, R.R.; Zhang, S.H. Gray Correlation Analysis on Employment and Its Influencing Factors. Liaoning Educ. Res. 2008, 5, 95-98.

32. Wang, Z.P.; Shi, C.L.; Li, Q.; Wang, G. Coupling trending analysis about urbanization and urban resource in Beijing. Energy Procedia 2011, 5, 1589-1596.

33. Ministry of Health of China; China National Standardization Committee. Standard Examination Methods for Drinking Water (GB5750-2006); China Standard Press: Beijing, China, 2007; pp. 39-446.

34. Ren, J.; Xiong, Y. An optimized method of weighting combination in multi-index comprehensive evaluation. Int. J. Appl. Decis. Sci. 2010, 3, 34-52.

35. Meng, X.L.; Fan, G.L.; Cao, X.H.; He, J.G.; Qu, J.H. Research on a multi-index comprehensive evaluation method for surface water quality assessment. Adv. Mater. Res. 2014, 1010-1012, 321-324. [CrossRef]

36. Ying, L. A study of drinking water quality index in Shanghai. J. Environ. Occup. Med. 2010, 27, $229-231$.

37. Li, Y.; Guo, T.T.; Zhou, J. Study on the Development of Rural Urbanization in Beijing. Procedia Environ. Sci. 2011, 11, 893-898. [CrossRef]

38. Browder, G.J.; Xie, S.Q.; Kim, Y.H.; Gu, L.X.; Fan, M.Y.; Ehrhardt, D. Stepping up_Improving the Performance of China's Urban Water Utilities; The World Bank: Washington, DC, USA, 2007; p. 26.

39. Deng, Y.X.; Brombal, D.; Farah, P.D.; Moriggi, A.; Critto, A.; Zhou, Y.; Marcomini, A. China's Water Environmental Management towards Institutional Integration. A Review of Current Progress and Constraints vis-a-vis the European Experience. Soc. Sci. Electron. Publ. 2015, 113, 285-298. [CrossRef]

40. Tiyip, T.P. Spatial different analysis of land Use/land cover change and human impact in typical Oasisin Arid Land. In Computer and Computing Technologies in Agriculture II; Springer: Boston, MA, USA, 2008; pp. 388-398. 
41. Li, Y.H.; Li, Y.R.; Westlund, H.; Liu, Y.S. Urban-rural transformation in relation to cultivated land conversion in China: Implications for optimizing land use and balanced regional development. Land Use Policy 2015, 417, 218-224. [CrossRef]

42. Lin, Z.L.; Anar, M.J.; Zheng, H.C. Hydrologic and water-quality impacts of agricultural land use changes incurred from bioenergy policies. J. Hydrol. 2015, 525, 429-440. [CrossRef]

43. Nelson, C.; Mchale, M.R.; Peterson, M.N. Influences of landscape and lifestyle on home energy consumption. Urban Ecosyst. 2012, 15, 773-793. [CrossRef]

44. Li, G.; Liu, W.; Wang, Z.; Liu, M. An empirical examination of energy consumption, behavioral intention, and situational factors: Evidence from Beijing. Ann. Oper. Res. 2016, 247, 1-18. [CrossRef]

(c) 2017 by the authors. Licensee MDPI, Basel, Switzerland. This article is an open access article distributed under the terms and conditions of the Creative Commons Attribution (CC BY) license (http:/ / creativecommons.org/licenses/by/4.0/). 